FACTA UNIVERSITATIS

Series: Economics and Organization Vol. 13, N $\mathrm{N}^{\mathrm{o}}$ 4, 2016, pp. 365 - 377

DOI: $10.22190 / F U E O 1604365 S$

Preliminary communication

\title{
FACTOR ANALYSIS OF TOTAL QUALITY MANAGEMENT ADOPTION BY SMES IN NIGERIA
}

UDC 005.6(662)

\author{
Ja'afaru Garba Sule ${ }^{1}$, Elijah E. Ogbadu ${ }^{1}$, Akeem Tunde Nafiu ${ }^{2}$ \\ ${ }^{1}$ Department of Business Administration, Kogi State University, Anyigba, Nigeria \\ ${ }^{2}$ Centre for Pre-Degree and Diploma Studies, Kogi State University, Anyigba, Nigeria
}

\begin{abstract}
This study focused on Total Quality Management (TQM) adoption by SMEs in Nigeria. The study investigated and analyzed factors responsible for TQM adoption by SMEs in Nigeria, its rate and success of the implementation and influence in competitive situation. Cross-sectional survey method was adopted to achieve these objectives. 250 SMEs were selected from manufacturing, textile, agricultural, food processing and service industries for data gathering; making the population of 2548, from which the sample size of 346 was determined using Taro Yamane method. The study found that the adoption of total quality management by SMEs is subject to many factors, and that TQM practices significantly affect different performance outcomes. Thus, the study concludes that TQM practice is another strategic option that can enhance viable performance outcome, and subsequently, competitive advantage of any SMEs at the marketplace. The study therefore recommends that SME owner-managers should invest substantial resources in adapting and implementing TQM in their operations so that success and viable performance outcome can be achieved.
\end{abstract}

Key words: Total Quality Management, performance outcomes, competitive advantage, communication, continuous improvement programs

\section{INTRODUCTION}

Today, the changes in both local and global competition inform SMEs of the need to improve on their efficiencies. Many researchers (Zhang, Waszink and Winjgaard, 2000; Antony, Leung, Knowles and Gosh, 2002) investigated the imperatives of Total Quality Management (TQM) as a better approach to enhancing efficiency and activeness in effective competition. TQM was viewed as an essential arm of operations management

Received September 15, 2016 / Revised November 15, 2016 / Accepted November 22, 2016

Corresponding author: Akeem Tunde Nafiu

Centre for Pre-Degree and Diploma Studies, Kogi State University, Anyigba, Nigeria

E-mail: tundenafiu01@gmail.com 
practices that is result oriented, and Heizer and Render (2004) asserted that the adoption and implementation of a set of operations management practices is one of many ways to win the competition in the marketplace. For businesses that would want to meet and exceed the expectations of their customers both at home and abroad, quality management practices is the strategy tool (Fening, 2012). Global competitiveness is a reality and quality is key to winning in the marketplace (Vokurka, 2001).

Recently, it has been observed that many small business owners now adopt Total Quality Management to win customers' patronage in Nigeria. Quality management is conceived to be a better approach to distinguishing their entrepreneurial activities in pursuit of a better pay-off in a competitive situation. Mustaph, Muda and Hasan (2011) posited that quality is very important in business today especially with product recalls and investigations as to what went wrong. Though, some SME owner-managers in Nigeria believe that the scope of their business has a great implication on the success or failure of the adoption and implementation of TQM. Few empirical studies (Ramsey 1998; Kuratko, Goodale and Hornsby, 2001) were conducted into finding out the rate and success of implementation of TQM in SMEs. Findings from these studies proved that the rate and success of implementation of TQM in SMEs is heavily insignificant. Studies in this regard are very scanty, but according to Husband and Mandal (1999), it appeared at the time of their study that SMEs have been very slow in implementing formal quality models, and where they have, the outcomes are inconclusive. Interestingly, this still remains apparent in Nigeria today. With great concern from their study, Fening (2012) stressed that Total Quality Management is seen as a tool to improve organizational performance in both large and small organizations and in any part of the world. The dimensions of the performance outcomes are financial performance, customer satisfaction, product/service quality performance and operational performance (Jaca and Psomas, 2015). Though, various studies have been conducted to examine the impact of TQM on financial performance, there is still disagreement concerning the effectiveness of TQM (Hansson and Eriksson, 2002). For example, Sadikoglu and Olcay (2014) asserted that TQM practices improve the financial performance of the firms; as against the research position of Ramsey (1998) and Kuratko et al. (2001). The factors responsible for TQM adoption by SMEs in Nigeria and the performance outcome of its implementation, in general, drive the focus of this study. Therefore, the main aim of this study is to investigate and analyze factors responsible for TQM adoption by SMEs in Nigeria. The study's specific objectives are:

1. To investigate the rate and success of the implementation of TQM by SMEs in Nigeria (in terms of customer preference, operation efficiency and product/service quality).

2. To investigate the influence of TQM practices on the competitive situation of SMEs in Nigeria.

\section{REVIEW OF RELEVANT LITERATURE}

\subsection{Concept of Total Quality Management (TQM)}

Total Quality management is an aged concept. According to Jung and Wang (2006), Total Quality Management has received great attention in the last two decades. A literature review of the previous studies on TQM evolved that researchers and academicians have 
defined TQM practices in different ways although they are complementary to each other (Prajogo and Sohal, 2003). In this regard, Sohal et al. (2010) identified five elements such as customer focus, management commitment, total participation, statistical quality control and systematic problem solving. Understanding the first element, Padhi (2016) stressed that total quality is a description of the culture, attitude and organization of a company that strives to provide customers with products and services that satisfy their needs.

According to Zairi (2009), TQM can be defined as the agreed company-wide and plant-wide operating work structure, documented in effective, integrated technical and managerial procedures, for guiding the coordinated actions of the people, the machines, and the information of the company and plant in the best and most practical ways to assure customer quality satisfaction and economical costs of quality. Pfau (2007) stated that TQM is an approach for continuously improving the quality of goods and services delivered through the participation of all levels and functions of the organization. Tobin (2004) views TQM as the totally integrated effort for gaining competitive advantage by continuously improving every facet of organizational culture. From the various view points of the authors, it could be depicted that TQM practice focuses on man, process and output; and these might have probably led authors into dimensioning TQM.

\subsection{Dimensions of Total Quality Management}

Price and Gaskill (2005) identified three dimensions of TQM as:

1. The product and service dimension: The degree to which the customer is satisfied with the product or service supplied. This involves the product reliability, durability and conformity.

2. The people dimension: The degree to which the customer is satisfied with the relationship with the people in the supplying organizations;

3. The process dimension: The degree to which the supplier is satisfied with the internal work processes, which are used to develop the products and services supplied to the customers.

Today's business world has posed various challenges to SMEs and this has often sprung up various researches into how customers can be better served. According to Khurshid, Kumar and Waddell (2012), QM has emerged as an effective competitive tool amongst these organizations.

\subsection{Total Quality Management: the cost and success of its practices by SMEs}

In Nigeria, it appears that the perception of SME owner-managers is that the cost of quality is tied up with the cost accrued to the production of a standard product. Gharakhani et al. (2013) explained that the cost of quality is considered by both Crosby and Juran to be the primary tool for measuring quality. The cost implication of not adopting TQM is relevant for the explanation of little or no growth or entropy of some SMEs within the shortest period of start-up. In the same vein, Khurshid et al. (2012) expressed that the costs associated with such issues are always significant and may result in the closure of businesses. Logically, a firm with a defective or rejected product will experience hike in the average cost of redoing a quality product, and this affects the financial scale of the business. Crosby referred to it as the price of nonconformance. 
Gharakhani et al. (2013) stated that the cost of prevention is less than the cost of correction. In addition, any compromise on quality by SMEs could also jeopardize the supply chain, resulting in raising costs because of poor quality (Kumar, 2007).

The cost of quality analysis will help SME owner-managers to focus on customer satisfaction, and therefore, enhance profitability and vibrant competitive position. According to Fryer et al. (2007), the importance of TQM practices for implementation is to increase the success rate, reduce delivery time, and prevent disillusioned state with continuous improvement programs. However, SME owner-managers need to bear in mind that the success of TQM practice depends among other on the following:

1. A review in the operating policy and processes for effective quality management.

2. Employee participation and commitment towards quality goal.

3. Customer focus quality management task.

4. Continuous improvement programs

5. Effective communication and teamwork.

Similarly, Ghobadain and Gaellar (1997) recommend that for successful TQM implementation providing clear direction and recognition for employees, an effective communication system, a progressive training program and realistic targets should be included.

However, Gharakhani et al. (2013) summarized the theory of total quality as follows:

1. Quality leads to lower costs as defects are reduced;

2. Quality is made in the boardroom; it cannot be instilled into shop floor without the initiative and commitment of top management;

3. Most defects are caused by the system, not the worker;

4. Inspection is too late; aim to reduce defects during production and eliminate mass inspection;

5. Eliminate numerical quotas, slogans, exhortation and targets for the workforce and promote sustained and continuous improvement of process and quality of output;

6. Drive out fear of change from workers; institute a vigorous program of education, training, and retaining to help the workforce improve continuously and to increase their job security;

7. Breakdown barriers between staff areas and abandon review systems that will destroy teamwork and create rivalry;

8. End the practice of awarding business on price tag alone; look for suppliers committed to quality and develop long term relationships with them.

\subsection{TQM Activities and small firm competitiveness}

According to Anderson and Mc Adam (2004), the evolution of the business environment over the past four decades has resulted in a need for improvements in business practices. TQM is a philosophy that small firms can use to improve their competitiveness. Khurshid et al. (2012) asserted that the business environment in which SMEs are operating demands quality at each operational step. Quality aspect is one of the most essential parameters in global competition today. The demand for better quality of product by customers in market place has made many companies provide quality product and services in order to compete in the marketplace successfully. To meet the challenge of this global competition, small firms can also invest substantial resources in adopting and implementing total quality management (TQM) 
practices in their operations. Khurshid et al. (2012) assumed that a rapid adoption of QM by enterprises has become an important determinant of success in the global market. For the adoption and implementation of TQM, SMEs stand the chance of winning the market and competitive advantage, and as well refurbishing their internal operating efficiencies. They need not only upgrade their critical operations and technologies, but are required to put some focus on QM issues as well (Khurshid et al., 2012). A strategy of high quality leads to a sustainable competitive advantage, (Porter, 1980).

Past studies have reported that the application of quality management practices in SMEs helps them to sharpen their market focus, use their material and human resources more efficiently and improve their competitive position in the market (Ahire and Golhar 1996). Continuous improvement can enable small scale enterprises to meet the competitive pressures of the global economy head-on, and to develop strategies for making products that are both high in quality and commercially successful. Khurshid et al. (2012) opined that it provides a foundation for the competitive pricing and ways of increasing profit margins. Obviously, competitive advantage required that a small scale enterprise possess one or more of the following capabilities when compared with its competitors, such as lower prices, higher quality, higher dependability, and shorter delivery time. Since small scale enterprises are faced with a competitive marketplace made up of these challenges, continuous improvement can be more than merely a formal or routine system of business management. Such continuous improvement can establish capabilities that will enhance the organization's overall performance (Mentzer et al., 2000).

Total Quality Management can be a success or failure depending on how well it is planned, implemented, measured and encouraged. However, the success of TQM premises on the communication channels, cooperation and culture embraced by both the SME owners and the employees.

\subsection{Implementing Total Quality Management}

The foundation problem with the workability of TQM is the weak status quo of ownermanagers' knowledge and skills regarding quality techniques. SME owner-managers have the sole-responsibility of conveying the philosophies of TQM to their employees, and this requires distinctive managerial Knowledge, Skill and Attitude (KSA). These among other factors remain essential ingredients of successful implementation of TQM.

However, Padhi (2016) opined that to be successful in implementing TQM, an organization must concentrate on the eight key elements such as ethics, integrity, trust, training, teamwork, leadership, recognition and communication. Padhi divided these elements into four groups as follow:

1. Foundation; which includes ethics, integrity and trust.

2. Build Bricks; which includes training, teamwork and leadership.

3. Binding Mortar; which includes communication

4. Roof; which includes recognition. 


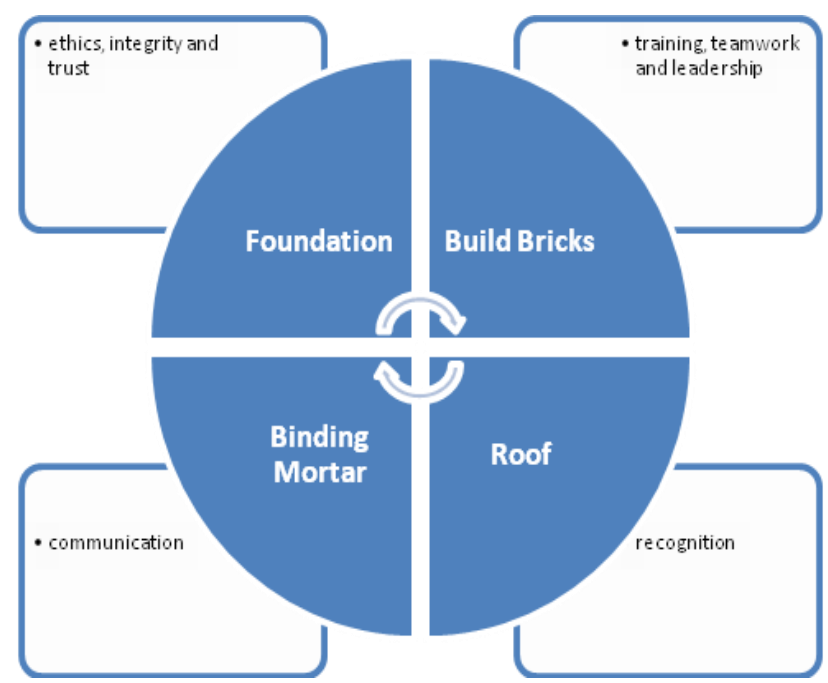

Fig. 1 Elements of successful TQM implementation Source: Adopted From Padhi (2016)

The first step in managing quality is building a platform for individual display of competence based on ethics, integrity, trust and recognition. In the real sense, ethics focuses on what is right or wrong as a guiding principle; integrity indicates honesty, moral values, fairness, and adherence to the facts and sincerity (Padhi, 2016); and Trust allows decision making at appropriate levels in the organization, fosters individual risk-taking for continuous improvement and helps to ensure that measurements focus on improvement of process and are not used to content people (Padhi, 2016).

\section{RESEARCH METHODS}

The objectives of this study stimulate the adoption of cross-sectional survey method. In their view, Aldridge and Levine (2001) believed that this survey design was useful due to its ability to predict behavior and assist researchers in collecting identical information concerning all the cases in a sample. In line with this, 250 SMEs were selected from manufacturing, textile, agricultural, food processing and service industries without considering the scale for data gathering. The population for this study was 2548 . The study determined its sample size of 346 using Taro Yamane method as shown below:

$$
n=\frac{N}{1+N(e)^{2}}
$$

where $\mathrm{n}=$ sample size $; \mathrm{N}=$ population of the study; $\mathrm{e}=$ error estimated at $5 \%(0.05)$.

$$
n=\frac{2548}{1+2548(0.05)^{2}}=\frac{2548}{1+2548(0.0025)}=\frac{2548}{1+6.37}=\frac{2548}{7.37}=346 \text { approximately }
$$




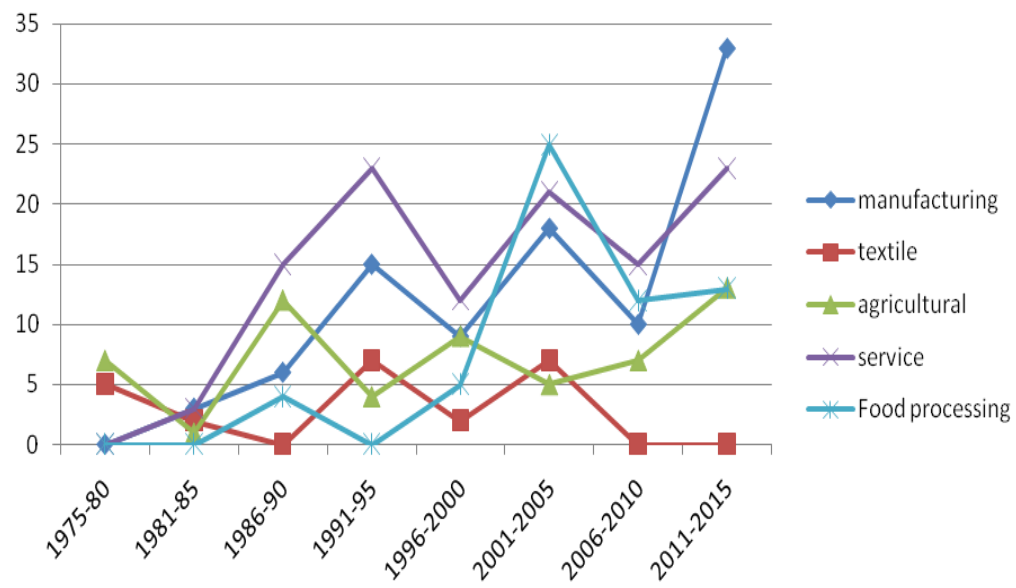

Fig. 2 Graphical illustration of sample spread across trends

From figure 2 above, it could be observed that the survey cut across SMEs that have existed within a timeframe considered being helpful to this study. For instance, ownermanagers of SMEs that have existed for at least five years were able to provide adequate data and information regarding the subject matter. Alexander, Davern and Stevenson (2010) opined that five years is often used as a yardstick for survival by demographers (to permit greater balancing of statistical power of test). To ensure unbiased data gathering process, multi-stage sampling techniques was adopted and simple random sampling techniques to select its required sample. This whole process of gathering data was carried out in collaboration with twelve research assistants. The instrument used for this study consists of items with $4 \& 5$-point scale for each.

\section{DATA PRESENTATION AND ANALYSIS}

Table 1 Questionnaire administration

\begin{tabular}{lcc}
\hline Questionnaire & Frequency & Percentage \\
\hline Ad min istered & 346 & 100 \\
Re trieved & 323 & 93.4 \\
Not Re trieved & 23 & 6.6 \\
\hline & Source: Field Survey, 2016
\end{tabular}

Table 1 reveals that the total questionnaires administered was $346(100 \%) ; 323$ questionnaires $(93.4 \%)$ were retrieved and 23 questionnaires $(6.6 \%)$ were not retrieved. Based on this, analysis was done on the number of questionnaires retrieved. 
Table 2 Demographic characteristics of the respondents

\begin{tabular}{lccc}
\hline Variabl s & Frequency & Percentage & Mean / Mode \\
\hline Age & 62 & 19.2 & 41 \\
$15-25$ & 59 & 18.3 & \\
$26-36$ & 87 & 26.9 & \\
$37-47$ & 73 & 22.6 & \\
$48-58$ & 42 & 13.0 & \\
$59 \&$ above & $\mathbf{3 2 3}$ & $\mathbf{1 0 0}$ & \\
Total & & & \\
Sex & 178 & 55.1 & \\
Male & 145 & 44.9 & \\
Female & $\mathbf{3 2 3}$ & $\mathbf{1 0 0}$ & \\
Total & & & \\
Educational Qualification & 59 & 18.3 & \\
FSLC & 92 & 28.5 & \\
SSCE & 97 & 30.0 & \\
NCE / OND / DIPLOMA & 50 & 15.5 & \\
HND / BSC & 25 & 7.7 & \\
MSC \& above & $\mathbf{3 2 3}$ & $\mathbf{1 0 0}$ & \\
Total & & & \\
Experience & 191 & 59.1 & \\
$0-10$ & 61 & 18.9 & \\
$11-20$ & 46 & 14.2 & \\
$21-30$ & 25 & $\mathbf{1 0 0}$ & \\
$31-40$ & $\mathbf{3 2 3}$ & & \\
Total & & & \\
\hline
\end{tabular}

Source: Field Survey, 2016

In table 2, it is revealed that 62 respondents (19.2\%) fall within the age range of 15 to 25 ; 59 respondents (18.3\%) fall within the age range of 26 to $36 ; 87$ respondents (26.9\%) fall within the age range of 37 to $47 ; 73$ respondents (22.6\%) fall within the age range of 48 to 58 ; and 42 respondents (13.0\%) fall within the age range of 59 and above. The value of the mean for the frequency of these age group indicates that majority of the respondents are 41 year old. Also, table 2 revealed that 178 respondents (55.1\%) were male; and 145 respondents $(44.9 \%)$ were female. The mode for this frequency of sex (168) indicates that majority of the respondents are male. In addition, the table revealed that 59 respondents (18.3\%) hold first school leaving certificate; 92 respondents (28.5\%) hold Senior School Certificate; 97 respondents (30.0\%) hold National Certificate (or its equivalent); 50 respondents (15.5\%) hold Higher National Diploma/ Bachelor of Science Certificate; and 25 respondents (7.7\%) hold Master of Science (or its equivalent) and above. Similarly also, the mode for this frequency of educational qualification (97) indicates that majority of the respondents have Higher National Certificate (or its equivalent). Finally, the table reveals that 191 respondents (59.1\%) have business experience of 0 to 10 years; 61 respondents 
(18.9\%) have experience of 11 to 20 years; 46 respondents $(14.2 \%)$ have experience of 21 to 30 years; and 25 respondents $(7.7 \%)$ have experience of 31 to 40 years. Likewise, the value of the mean for the frequency of experiences indicates that majority of the respondents have business experience of 12 years.

Table 3 Factors responsible for TQM adoption by SMEs in Nigeria

\begin{tabular}{|c|c|c|c|c|c|c|c|c|c|c|c|c|}
\hline Various factors & VGE & $\overline{\text { GE }}$ & $\mathbf{L E}$ & VLE & Total & TVGE & TGE & TLE & TVLE & Total & $\begin{array}{l}\text { Mean } \\
\text { Score }\end{array}$ & Remark \\
\hline $\begin{array}{l}\text { Adequate resource } \\
\text { availability }\end{array}$ & 106 & 83 & 54 & 80 & 323 & 424 & 249 & 108 & 80 & 861 & 2.7 & $\begin{array}{c}\text { Moderately } \\
\text { high }\end{array}$ \\
\hline $\begin{array}{l}\text { Technology } \\
\text { advancement }\end{array}$ & 79 & 85 & 96 & 63 & 323 & 316 & 255 & 192 & 63 & 826 & 2.6 & $\begin{array}{c}\text { Moderately } \\
\text { high }\end{array}$ \\
\hline $\begin{array}{l}\text { Quality assurance } \\
\text { knowledge }\end{array}$ & 112 & 91 & 74 & 46 & 323 & 448 & 273 & 148 & 46 & 915 & 2.8 & $\begin{array}{c}\text { Moderately } \\
\text { high }\end{array}$ \\
\hline $\begin{array}{l}\text { Managerial } \\
\text { planning }\end{array}$ & 126 & 75 & 56 & 66 & 323 & 504 & 225 & 112 & 66 & 907 & 2.8 & $\begin{array}{c}\text { Moderately } \\
\text { high }\end{array}$ \\
\hline $\begin{array}{l}\text { Communication } \\
\text { channels }\end{array}$ & 98 & 102 & 28 & 95 & 323 & 392 & 306 & 56 & 95 & 849 & 2.6 & $\begin{array}{c}\text { Moderately } \\
\text { high }\end{array}$ \\
\hline $\begin{array}{l}\text { Cooperation } \\
\text { and business culture }\end{array}$ & 107 & 80 & 36 & 100 & 323 & 428 & 240 & 72 & 100 & 840 & 2.6 & $\begin{array}{c}\text { Moderately } \\
\text { high }\end{array}$ \\
\hline
\end{tabular}

Table 3 above indicates that factors such as adequate resource availability with mean score of 2.7, technology advancement having a mean score 2.6, quality assurance knowledge with mean score 2.8, managerial planning with mean score of 2.8, Communication channels with mean score of 2.8, Communication channels with mean score of 2.6, and Cooperation and business culture with mean score of 2.6 respectively were observed to be moderately responsible for TQM Adoption by SMEs in Nigeria.

Table 4 Responses on rate and success of the implementation of TQM by SMEs in Nigeria

\begin{tabular}{|c|c|c|c|c|c|c|c|}
\hline \multirow[t]{2}{*}{ Question } & \multicolumn{5}{|c|}{ Frequency } & \multirow[b]{2}{*}{ Mean Score } & \multirow[b]{2}{*}{ Cutoff Point } \\
\hline & VGE(\%) & GE(\%) & ME $(\%)$ & $\mathbf{L E}(\%)$ & VLE $(\%)$ & & \\
\hline 1. Customer satisfaction & $85(26.3)$ & $92(28.5)$ & $59(18.3)$ & $23(7.1)$ & $64(19.8)$ & 3.344 & 3.050 \\
\hline 2. Market share & $84(26.0)$ & $53(16.4)$ & $64(19.8)$ & $79(24.5)$ & $43(13.3)$ & 3.173 & 3.050 \\
\hline 3. Financial performance & $102(31.6)$ & $47(14.6)$ & $50(15.5)$ & $87(26.9)$ & $37(11.5)$ & 3.279 & 3.050 \\
\hline 4. Process improvement & $24(7.4)$ & $142(44.0)$ & $86(26.6)$ & $15(4.6)$ & $56(17.3)$ & 3.195 & 3.050 \\
\hline 5. Product / Service quality & $73(22.6)$ & $83(25.7)$ & $97(30.0)$ & $25(7.7)$ & $45(13.9)$ & 3.353 & 3.050 \\
\hline
\end{tabular}

Table 4 shows the responses regarding the rate and success of the implementation of TQM by SMEs in Nigeria. 85 respondents $(26.3 \%)$ opined customer satisfaction to a very great extent; 92 respondents $(28.5 \%)$ opined to a great extent; 59 respondents $(18.3 \%)$ opined to a moderate extent; 23 respondents (7.1\%) opined low extent; and 64 respondents $(19.8 \%)$ opined very low extent. It is observed that the mean score of 
customer satisfaction is 3.344 which are greater than the cut-off point. However, this result shows a moderately high indicator of success. This implies that the implementation aspect of quality decision is strategically focused on capturing the interest and serving the demand of the customers satisfactorily without compromising their expectations to a reasonable extent.

For question two, the table shows that 84 respondents $(26.0 \%)$ are observed to have had market share to a very great extent; 53 respondents $(16.4 \%)$ are observed to have had market share to a great extent; 64 respondents $(19.8 \%)$ are observed to have had market share to a moderate extent; 79 respondents $(24.5 \%)$ are observed to have had market share to a low extent; and 43 respondents $(13.3 \%)$ are observed to have had market share to a very low extent. It is observed that the mean score of responses (regarding market share) is 3.173 which is slightly greater than the cut-off point. Though, the mean score appears to be high; the result shows a weak indicator of success. This implies that market share of SMEs in Nigeria is a less significant measure of their successful implementation of TQM.

Question three focused on financial performance as an indicator of success in the implementation of TQM by SMEs in Nigeria, the table shows that 102 respondents $(31.6 \%)$ agreed to a very great extent; 47 respondents $(14.6 \%)$ agreed to a great extent; 50 respondents $(15.5 \%)$ agreed to a moderate extent; 87 respondents $(26.9 \%)$ opined low extent; and 37 respondents $(11.5 \%)$ opined very low extent. The table depicts that the mean score of responses based on financial performance is 3.279 greater than the cut-off point. The mean score shows that financial performance is a moderate indicator of success. Hence, financial performance of SMEs in Nigeria is an evidence of moderate implementation of TQM.

Question four focused on process improvement as an indicator of success in the implementation of TQM by SMEs, the table shows that 24 respondents (7.4\%) agreed to a very great extent; 142 respondents $(44.0 \%)$ agreed to a great extent; 86 respondents $(26.6 \%)$ agreed to a moderate extent; 15 respondents (4.6\%) opined low extent; and 56 respondents $(17.3 \%)$ opined very low extent. The mean score of these responses is 3.195; greater than the cut-off point. This shows that SME owner-managers have not given severe attention to process improvement recently. Hence, process improvement of SMEs is weak indicator of successful implementation of TQM in Nigeria.

Question five focused on product/service quality as an indicator of success in the implementation of TQM by SMEs, the table shows that 73 respondents $(22.6 \%)$ have improved to a very great extent; 83 respondents $(25.7 \%)$ have improved to a great extent; 97 respondents $(30.0 \%)$ improved moderately; 25 respondents $(7.7 \%)$ improved to a low extent; and 45 respondents $(13.9 \%)$ improved to a very low extent. The mean score of these responses is 3.353; greater than the cut-off point. This shows that SME ownermanagers have given moderately severe attention to product/service quality improvement recently. Hence, product/service quality improvement of SMEs is a moderate indicator of successful implementation of TQM in Nigeria.

However, rate and success of implementation is taken as the performance outcome of TQM adoption by SMEs in Nigeria. The findings of this present study thus agree with the results of Sadikoglu and Olcay (2014) which revealed that different TQM practices significantly affect different performance outcomes. The findings above advance the studies of Ramsey (1998) and Kuratko et al. (2001) which proved that the rate and success 
of implementation of TQM in SMEs is heavily insignificant. It is lately discovered that TQM implementation has assumed a moderate success in SMEs. SME owners' emotional attachment, communication, knowledge, skill, commitment and other efforts towards ensuring customer satisfaction, better market share, financial performance, process improvement and product/service quality are significant to moderate implementation of TQM in Nigeria.

\section{CONCLUSION AND RECOMMENDATIONS}

The adoption of total quality management by SMEs is subject to many factors such as adequate resource availability, technology advancement, quality assurance knowledge, managerial planning, communication channels, cooperation and business culture respectively. These factors appear to be moderately responsible for TQM adoption by SMEs in Nigeria.

The rate and success of implementation or the performance outcome of TQM adoption by SMEs in Nigeria seem to have a positive relationship with TQM practice. It remains unnoticed to a very high degree that TQM has influence on SMEs' performance outcome. The underlying fact is that different performance outcomes are subject to different TQM practices. The position of some studies with the reverse result that the rate and success of implementation of TQM in SMEs is heavily insignificant may be probably defective. The empirical verification proves that TQM implementation has assumed a moderate success in SMEs from Nigeria with concomitant performance outcome. TQM is the continuous improvement of quality to meet expected outcomes. There is no way TQM can be left out of business success today, especially with product recalls and investigation problems and proffering solutions. Thus, the practice of TQM is another strategic option that can enhance viable performance outcome, and subsequently, competitive advantage of any small firm at the marketplace.

Based on the findings of this study, it is recommended that:

1. SME owner-managers should invest substantial resources in adapting and implementing Total Quality Management (TQM) in their operations so that success and viable performance outcome can be achieved.

2. SME owner-managers should select and use the most convenient tool of Total Quality Management.

3. In the course of adoption of TQM, SME owner-managers should take into consideration factors such as adequate resource availability, technology advancement, adequate quality assurance knowledge, effective managerial planning, effective communication channels, cooperation and well designed business culture for organizational family affairs.

\section{REFERENCES}

Ahire, S.L. \& Golhar, D.Y. (1996). Quality management in large vs. small firms, Journal of Small Business Management, 13(2), 1-13.

Anderson, K. \& McAdam, R. (2004). A critique of benchmarking and performance measurement, lead or lag?, Benchmarking: An International Journal, 11(5), 465-483.

Antony, J.; Leung, K., Knowles, G. \& Gosh, S. (2002), Critical success factors of TQM implementation in Hong Kong industries, International Journal of Quality and Reliability Management, 19(5), 551-556.

Crosby, P.B. (1995). Quality without Tears: The art of hassle-free management. New York: McGraw-Hill 
Fening, F.A. (2012). Impact of Quality Management Practices on the Performance and Growth of Small and Medium Sized Enterprises (Smes) in Ghana. International Journal of Business and Social Science. 3(13), 1-13.

Fryer K.J., et al. (2007), Critical Success Factors of Continuous Improvement in the Public Sector: A Literature Review and Some Key Findings. The TQM Magazine. 19(5), 497-517.

Gharakhani, D., Rahmal, H., Farrokhi, R.M. \& Farahmandian, A. (2013), Total Quality Management and Organizational Performance, American Journal of Industrial Engineering, 1(3), 46-50.

Ghobadain, A. \& Gallear, D. (1997). TQM and Organization size. International Journal of Operations and Production Management, 17(2), 121-163.

Hansson, J. \& Eriksson, H. (2002). The Impact of TQM on Financial Performance. Measuring Business Excellence, 6(4), 44-54.

Heizer, J. \& Barry R. (2004), Operation Management, 7th Edition, USA: Pearson Prentice Hall Inc.

Husband, S. \& Mandal, P. (1999). Perceptions and Realities of Quality Methods in Australian Small-to Medium-sized Enterprises. Victoria University of Technology: Proceedings of the 12th Annual SEAANZ Conference, 143-157.

Jaca, C. \& Psomas, E. (2015). Total Quality Management Practices and Performance Outcomes in Spanish Service Companies. Total Quality Management and Business Excellence. 26(9-10).

Jung, J. \& Wang, Y. (2006), Relationship between total quality management (TQM) and continuous improvement of international project management (CIIPM), Technovation, 26(5), 716-722.

Khurshid, K.K., Kumar, M. \& Waddell, D. (2012). Status of Quality Management in Australian Manufacturing SMEs. Istanbul, Turkey: International Conference on Industrial Engineering and Operations Management, 1266-1275

Kumar, M., (2007), Critical success factors and hurdles to Six Sigma implementation: the case of a UK manufacturing SME. In K.K. Khurshid, M. Kumar \& D. Waddell (eds). Status of Quality Management in Australian Manufacturing SMEs. Istanbul, Turkey: International Conference on Industrial Engineering and Operations Management, 1266-1275

Kuratko, D.F., Goodale, J.C. \& Hornsby, J.S. (2001). Quality Practices for a Competitive Advantage in Smaller Firms. Journal of Small Business Management, 39(4): 293-311.

Mentzer J.T, Min S. \& Zacharia Z.G. (2000), The nature of inter-firm partnering in supply chain management. Journal of Retail, 7(6), 549-568.

Mustaph, M.R., Muda, M.S. \& Hasan, F.A. (2011), A Survey of Total Quality Management in the Malaysian Small and Medium Sized Manufacturing Companies, International Journal of Humanities and Social Science, 1(2), 1-12.

Padhi, N. (2016). Methodology Total Quality Management. Retrieved from: https://www.isixsigma.com/ methodology/total-quality-management-tqm/eight-elements-tqm/

Pfau, L.D. (2007), TQM Gives Companies a Way to Enhance Position in Global Market Place, Industrial Engineering, 21( 4), 77-87.

Porter, M. (1980), Competitive Strategy. In D. Gharakhani, H. Rahmal, R.M. Farrokhi and A. Farahmandian (eds.), Total Quality Management and Organizational Performance, American Journal of Industrial Engineering, 1(3), 46-50.

Prajogo D.I. (2005), The Comparative Analysis of TQM Practices and Quality Performance between Manufacturing and Service Firms, International Journal of Service Industry Management. 1(6), 217-228.

Price, R.C. \& Gaskill, G.P. (2005), Total Quality Management in Research-Philosophy and Practice, Total Quality Management-3: Proceedings of 5th International Conference, 77-87.

Rahman, S. (2001a). A comparative study of TQM practice and organizational performance of SMEs with and without ISO 9000 certification, International Journal of Quality \& Reliability, 18(1), 35-49.

Ramsey, J. (1998). The Value of ISO 9000 Certification to a Small Business, Proceedings: Second International and Fifth National Research Conference on Quality Management, February, 145-156.

Sadikoglu, E. \& Olcay, H. (2014). The Effects of Total Quality Management Practices on Performance and the Reasons of and the Barriers to TQM Practices in Turkey. Advances in Decision Science. 17.

Sohal, A.S., Tay, G.S. \& Wirth, A. (2010), Total Quality Control in the Asian Division of a Multinational Corporation, International Journal of Quality and Reliability Management, 6 (6): 60-74.

Tobin, L.M. (2004), The New Quality Landscape: TQM, International Journal of Systems Management, 41(11), 10-14.

Vokurka, R. (2001). Using the Aldridge criteria for personal quality improvement. Industrial Management + Data Systems. 101(7), 363-369.

Zaire, M. (2009), Total Quality Management for Engineers, Cambridge: Woodhead.

Zhang, Z. Waszink, A. \& Winjgaard, J. (2000), An instrument for measuring TQM implementation for Chinese manufacturing companies, International Journal of Quality and Reliability Management, 17(7), 730-755. 


\section{ANALIZA FAKTORA USVAJANJA TOTALNOG UPRAVLJANJA KVALITETOM (TQM) OD STRANE MALIH I SREDNJIH PREDUZEĆA U NIGERIJI}

Ova studija fokusira se na usvajanje Totalnog upravljanja kvalitetom (TQM) od strane malih i srednjih preduzeća u Nigeriji. Studija je ispitivala i analizirala faktore odgovorne za usvajanje TQM od strane malih $i$ srednjih preduzeća u Nigeriji, njihovu brzinu i uspeh u implementaciji $i$ uticaj na situacije konkurentnosti. Usvojen je metod istraživanja poprečnog preseka za postizanje ovih ciljeva. Odabrano je 250 MSP iz proizvodnih, tekstilnih, poljoprivrednih, prehrambenih $i$ uslužnih delatnosti za prikupljanje podataka; ukupno 2548 ispitanika, od kojih je određena veličina uzorka od 346 korišćenjem Taro Yamane metoda. Studija je pokazala da je usvajanje ukupnog upravljanja kvalitetom MSP podložno mnogim faktorima, a da praksa TQM značajno utiče na različite ishode performansi. Tako, studija zaključuje je da TQM praksa još jedna strateška opcija koja može poboljšati održiv ishod performansi, a kasnije konkurentsku prednost malih i srednjih preduzeća na tržištu. Studija stoga preporučuje da bi vlasnici-menadžeri MSP trebalo da ulože značajna sredstva u prilagođavanje i sprovođenje TQM u svom radu tako da se može postići uspeh i održivi ishod učinka.

Ključne reči: Menadžment totalnim kvalitetom, Ishodi performansi, konkurentska prednost, komunikacija, programi kontinuiranog poboljšanja 